BUDGET

PERSPECTIVES

2021

PAPER 3

May 2020

\section{THE EFFECT OF THE COVID-19 PANDEMIC ON CONSUMPTION AND INDIRECT TAX IN IRELAND}

CATHAL COFFEY, KARINA DOORLEY, CONOR O'TOOLE AND BARRA ROANTREE

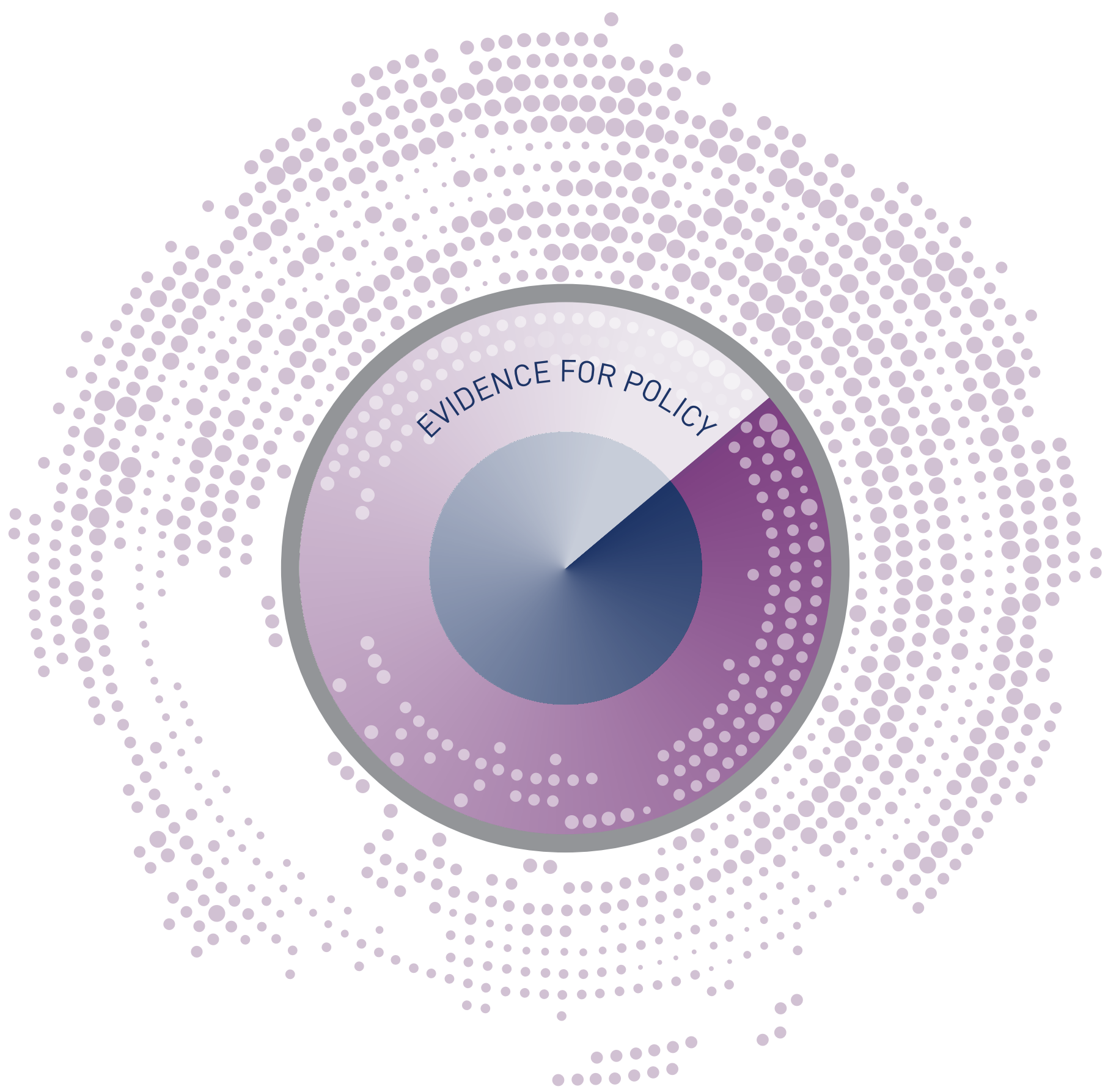

\title{
od
}

ESR| ${ }_{\text {RESEARCH INSTITUTE }}^{\text {ECONOMIC \& SOCIAL }}$ 


\section{The effect of the COVID-19 pandemic on consumption and indirect \\ tax in Ireland}

Cathal Coffey

Karina Doorley

Conor O'Toole

Barra Roantree

May 2020

\section{BUDGET PERSPECTIVES 2021}

\section{PAPER 3}

Available to download from www.esri.ie

https://doi.org/10.26504/bp202103.pdf

(C) 2020 The Economic and Social Research Institute Whitaker Square, Sir John Rogerson's Quay, Dublin 2

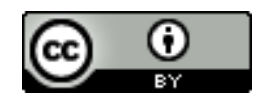

This Open Access work is licensed under a Creative Commons Attribution 4.0 International License (https://creativecommons.org/licenses/by/4.0/), which permits unrestricted use, distribution, and reproduction in any medium, provided the original work is properly credited. 



\section{ABOUT THE ESRI}

The mission of the Economic and Social Research Institute is to advance evidencebased policymaking that supports economic sustainability and social progress in Ireland. ESRI researchers apply the highest standards of academic excellence to challenges facing policymakers, focusing on 12 areas of critical importance to 21st Century Ireland.

The Institute was founded in 1960 by a group of senior civil servants led by Dr T. K. Whitaker, who identified the need for independent and in-depth research analysis to provide a robust evidence base for policymaking in Ireland.

Since then, the Institute has remained committed to independent research and its work is free of any expressed ideology or political position. The Institute publishes all research reaching the appropriate academic standard, irrespective of its findings or who funds the research.

The quality of its research output is guaranteed by a rigorous peer review process. ESRI researchers are experts in their fields and are committed to producing work that meets the highest academic standards and practices.

The work of the Institute is disseminated widely in books, journal articles and reports. ESRI publications are available to download, free of charge, from its website. Additionally, ESRI staff communicate research findings at regular conferences and seminars.

The ESRI is a company limited by guarantee, answerable to its members and governed by a Council, comprising 14 members who represent a cross-section of ESRI members from academia, civil services, state agencies, businesses and civil society. The Institute receives an annual grant-in-aid from the Department of Public Expenditure and Reform to support the scientific and public interest elements of the Institute's activities; the grant accounted for an average of 30 per cent of the Institute's income over the lifetime of the last Research Strategy. The remaining funding comes from research programmes supported by government departments and agencies, public bodies and competitive research programmes.

Further information is available at www.esri.ie. 


\section{THE AUTHORS}

Cathal Coffey is a Research Assistant at the ESRI. Karina Doorley is a Senior Research Officer at the ESRI and an Adjunct Associate Professor at TCD. Barra Roantree is a Research Officer at the ESRI and an Adjunct Assistant Professor at TCD. Conor O'Toole is a Senior Research Officer at the ESRI and an Adjunct Associate Professor at TCD.

\section{ACKNOWLEDGEMENTS}

We are grateful to the Irish Social Science Data Archive for facilitating access to the Household Budget Survey (HBS). This work was carried out with funding from the ESRI's Tax, Welfare and Pensions Research Programme (supported by the Department of Public Expenditure and Reform, the Department of Employment Affairs and Social Protection, the Department of Health, the Department of Children and Youth Affairs and the Department of Finance), which is gratefully acknowledged. The analysis uses the indirect tax model, ITSim, jointly developed by researchers from the ESRI and the Department of Finance. We thank Keelan Beirne for excellent research assistance.

This paper has been accepted for publication by the Institute, which does not itself take institutional policy positions. The paper has been peer reviewed prior to publication. The authors are solely responsible for the content and the views expressed. 


\section{TABLE OF CONTENTS}

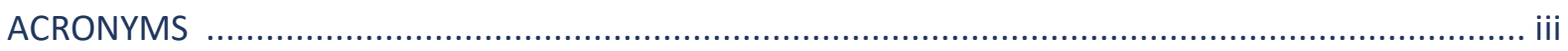

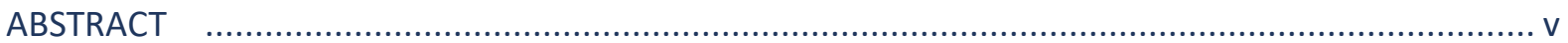

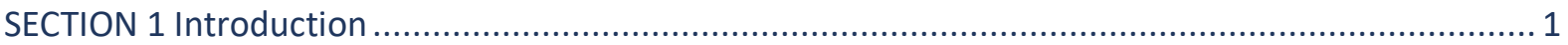

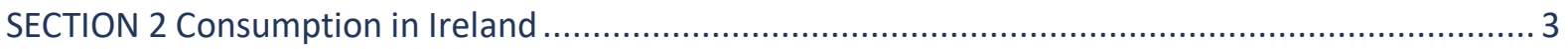

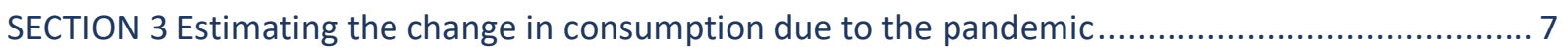

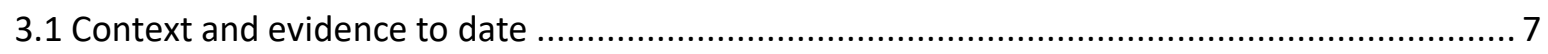

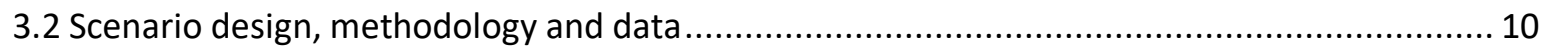

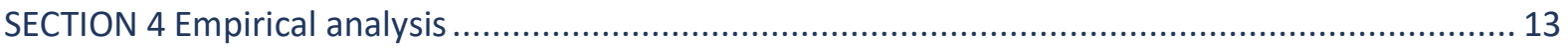

4.1 Pandemic changes to household consumption...................................................... 13

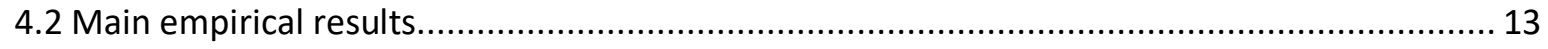

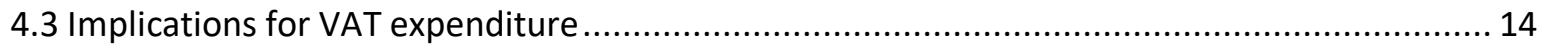

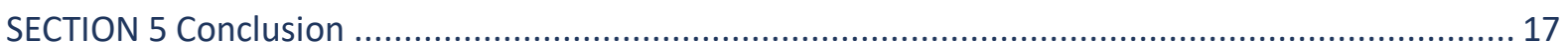

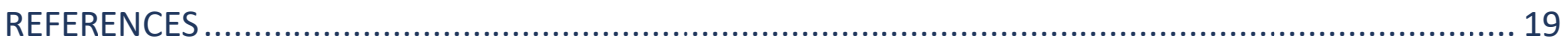

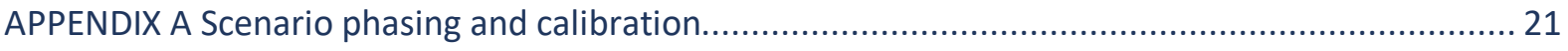

APPENDIX B Microdata and parameterisation.......................................................... 23 


\section{LIST OF TABLES}

Table 1 Retail sales in Ireland (seasonally adjusted), January-March 2020 ............................. 9

Table 2 Developments in personal credit and debit card expenditure ..................................... 10

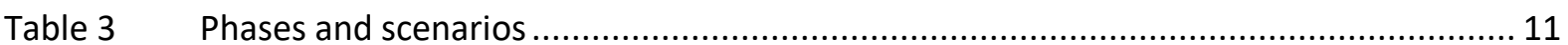

Table 4 Figures for expenditure in a typical phase week - Deviations from case case (\%) ......... 13

Table 5 Annual changes to consumption by scenario (\%) .................................................... 14

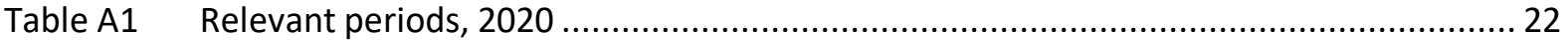

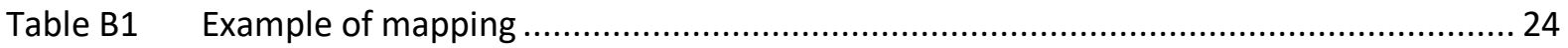

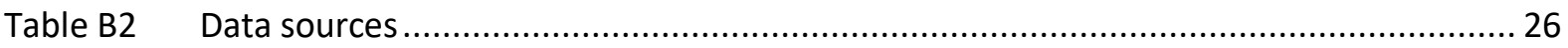

\section{LIST OF FIGURES}

Figure 1 Composition of aggregate household expenditure .................................................... 3

Figure 2 Spending shares by income quintile, household type and housing tenure ...................... 5

Figure 3 Average weekly indirect tax paid per household in each phase of the pandemic ( $€$ per

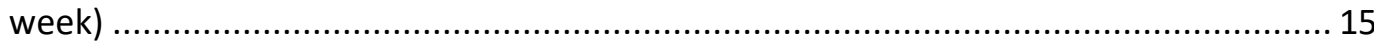

Figure 4 Simulated change in indirect tax revenue under different pandemic scenarios

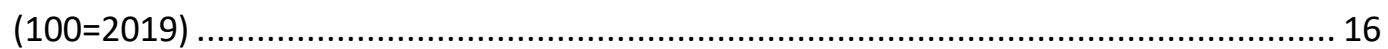

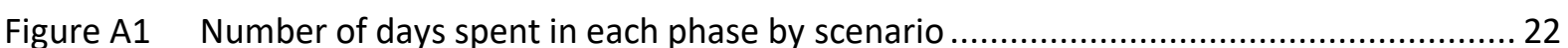




\section{ACRONYMS}

$\begin{array}{ll}\text { CBI } & \text { Central Bank of Ireland } \\ \text { CSO } & \text { Central Statistics Office } \\ \text { HBS } & \text { Household Budget Survey } \\ \text { ITSim } & \begin{array}{l}\text { Indirect tax microsimulation model developed by ESRI and } \\ \text { Department of Finance }\end{array} \\ \text { PUP } & \text { Pandemic Unemployment Payment } \\ \text { RAI } & \text { Restaurants Association of Ireland } \\ \text { SIMI } & \text { Society of the Irish Motor Industry } \\ \text { TWSS } & \text { Temporary Wage Subsidy Scheme }\end{array}$





\section{ABSTRACT}

Using micro data from the Central Statistics Office (CSO) Household Budget Survey (HBS), we assess the effect of the COVID-19 pandemic on consumption and its implications for indirect tax receipts in 2020. We show that over one-third of household expenditure is on items that are currently restricted due to public health measures such as transport, selected retail expenditure and entertainment items. We parameterise three scenarios which attempt to take into account: 1) a return to a 'new normal' with ongoing physical and social distancing; 2) a 'second wave' lockdown; and 3) rapid vaccine development that allows a return to normal economic and social life by the end of 2020. Under these scenarios, household consumption this year is estimated to be between 12 and 20 per cent lower than what it would have been in the absence of the pandemic. Indirect tax paid by households is estimated to be between 19 and 32 per cent lower than it otherwise would have been. 



\section{SECTION 1}

\section{Introduction}

Many households have seen a fall in their disposable income as a result of the public health measures necessary to contain the spread of COVID-19 in Ireland. A decline in disposable income usually leads to a fall in consumption. However, the COVID-19 pandemic has also induced a reduction in consumption due to enforced business closures and social distancing measures.

In this report, we document consumption patterns in Ireland using the 2015-2016 Household Budget Survey (HBS). We compare the proportion of household spending that can be categorised as 'essential' to that which is typically devoted to items that are now more difficult or impossible to consume (such as haircuts, tickets to sporting events, etc.). We show how the ratio of 'essential' to other spending differs by household income and type and draw inference on how the current lockdown will impact certain sectors, and on how the likely continuation of social distancing through 2020 will impact household spending. Then, using parameters drawn from real-time data on recent consumption changes in Ireland and elsewhere, we simulate the impact of the COVID-19 pandemic on consumption in Ireland in 2020 and estimate what this reduction in consumption means for indirect tax revenue.

We calibrate three scenarios built around the phased reopening of economic and social life associated with the current Government Roadmap for Reopening Society and Business. ${ }^{1}$ These scenarios are as follows: a) a 'new normal' scenario, whereby Ireland re-opens in line with the Roadmap but continued physical and social distancing are required to the end of 2020;2) a 'second wave' scenario, whereby a strict lockdown is re-imposed in the final quarter of 2020 due to a reoccurrence of widespread viral transmission; and 3) a 'vaccine' scenario, whereby rapid vaccine development allows normal economic life to return by Quarter 4 of 2020.

To programme these scenarios, we rely on a number of inputs. Firstly, Central Statistics Office (CSO) retail sales data and Central Bank of Ireland credit card data, both for March 2020, point to a sharp reduction in expenditure by households. This backs up emerging international evidence, which points towards major declines in household spending internationally (Chen et al., 2020; Baker et al., 2020). Using these data and international evidence, we simulate expenditure changes under both the strict lockdown imposed in March as well as through the various phases of the government Roadmap out to August 2020. We then parameterise the final quarter of the year depending on whether: a) social distancing continues; b) a 
second wave emerges; or c) a medical breakthrough allows a rapid improvement in economic conditions.

The results suggest that household spending will be between 12 and 20 per cent lower in 2020 than 2019. In the scenario whereby economic activity resumes with social distancing, we estimate spending will be 13 per cent lower in 2020. In this scenario, expenditure on clothing and footwear is 25 per cent lower while expenditure on transport is 34 per cent below 2019 levels. In the severe, second wave scenario, spending is down 20 per cent relative to normal, with falls for durables, clothing and footwear and transport all above, or close to, 40 per cent lower than normal. The knock-on effect of the decline in consumption on indirect tax is estimated to be between 19 and 32 per cent, depending on the scenario. The scale of the economic shock from the COVID-19 pandemic is clearly illustrated by the fact that, in the scenario which allows for a return to normal economic and social life with a vaccine in the fourth quarter of 2020, spending is still estimated to be 12 per cent lower than 2019 and indirect tax is estimated to be 19 per cent lower than it otherwise would have been.

By using real-time parameters for observed changes in consumption, the effects estimated in this report simultaneously take into account the effect of public health restrictions on consumption and changes in disposable income. However, it is not possible to separately identify these effects. The parameters used to simulate the change in consumption combine information about the supply of goods and services and the demand for these goods and services.

The rest of this paper is structured as follows: Section 2 presents an overview of household spending in Ireland; Section 3 presents the scenarios deployed in our analysis; Section 4 presents the empirical findings; and Section 5 concludes. 


\section{SECTION 2}

\section{Consumption in Ireland}

Figure 1 shows the composition of overall household spending in Ireland, using data from the latest edition of the HBS (2015-2016). Expenditure is uprated to 2020 levels using price growth indices but the relative share of each item in the consumption bundle is assumed to remain constant (see Appendix A for further detail). We classify spending on housing costs, groceries, fuel and light and medical expenses as 'essentials', with these items amounting to 38 per cent of total expenditure. Within this category, housing costs and groceries are the main spending items, representing close to one-third of overall household consumption.

Given the current public health measures in place, we classify as 'restricted' spending on transport, clothing, holidays, durables, drink and tobacco, meals out and some miscellaneous items (primarily hairdressing and sport/leisure admission charges). ${ }^{2}$ Together, these account for more than one-third of household consumption (36.1 per cent), with spending on 'other' items making up the residual (25.6 per cent).

\section{FIGURE 1 COMPOSITION OF AGGREGATE HOUSEHOLD EXPENDITURE}
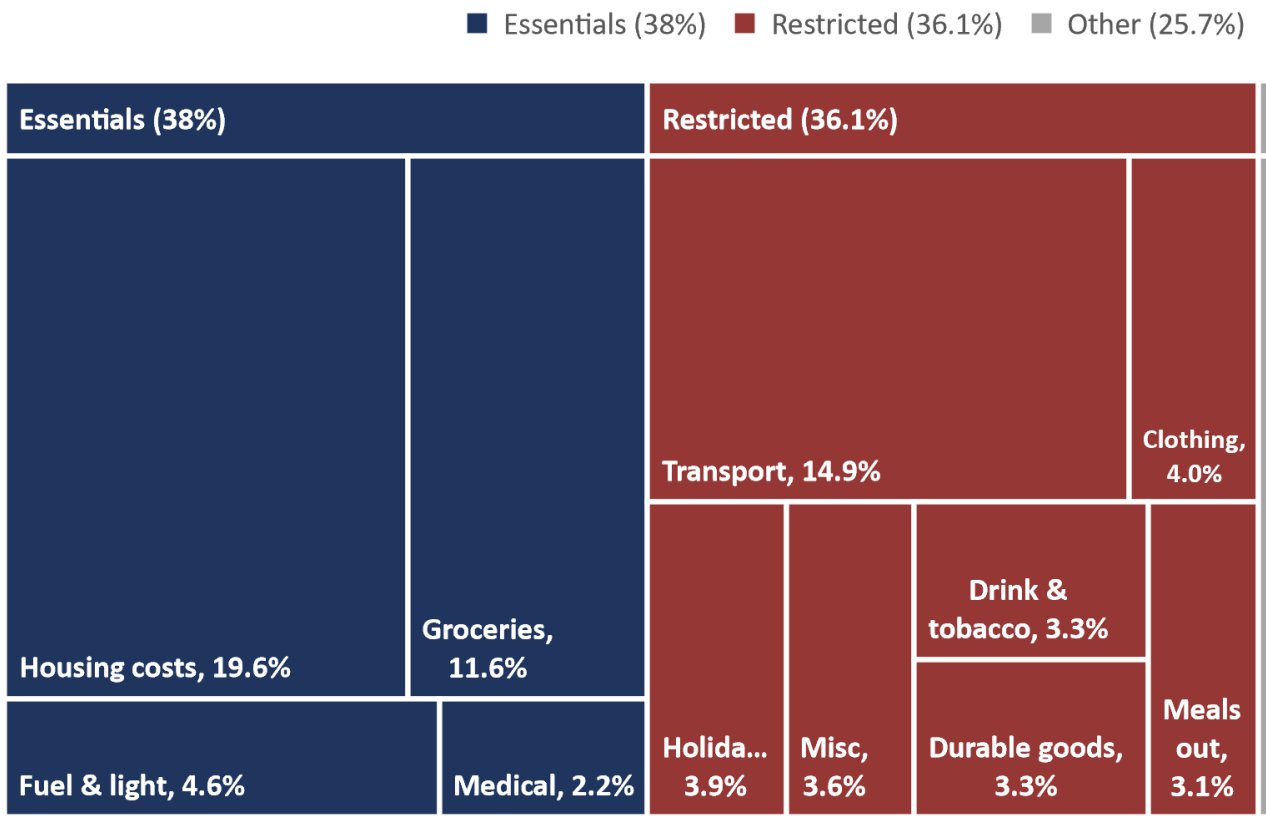

Other $(25.7 \%)$

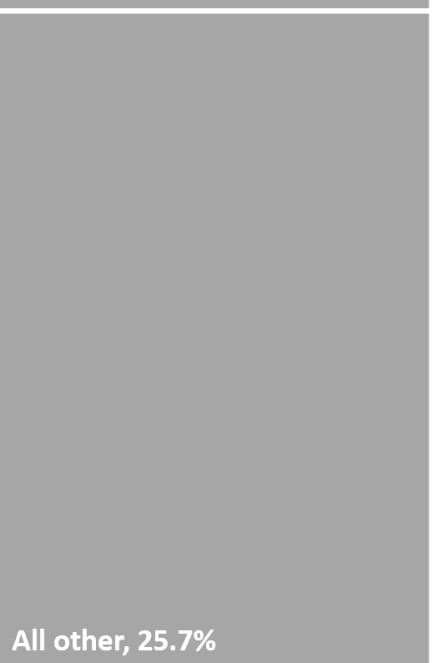

Source: Authors' calculations using 2015-2016 HBS.

Notes: 'Housing costs' include rental costs as well as mortgage interest and capital payments. Restricted 'misc' category comprises expenditure on 'sports and leisure admission and subscription charges; hairdressing and personal grooming; and reading material'. 'Drink and tobacco' includes spending in both on and off-license premises. Percentages above may be affected by rounding error. 
Figure 2 shows how these spending shares vary by income, family type and housing tenure. The share of essential goods in the household budget is larger for low income, single and renting families. As a result, these types of families may find it more difficult than others to weather a sustained income shock, in particular since they - on average - have less savings to draw on (CSO, 2020a).

By contrast, higher-income families, couples and owner occupiers spend proportionally more on restricted goods and services. While some of the spending foregone on these items during the pandemic may be recovered as sectors of the economy begin to open up, much of this expenditure is on experiences (such as holidays or meals out), which may take significant time to recover (Keogh-Brown et al., 2010). This could lead to higher rates of savings among households that are either not directly affected by job loses or pay reductions or that have any decline in income cushioned by the new income supports introduced by the Government (Beirne et al., 2020). 

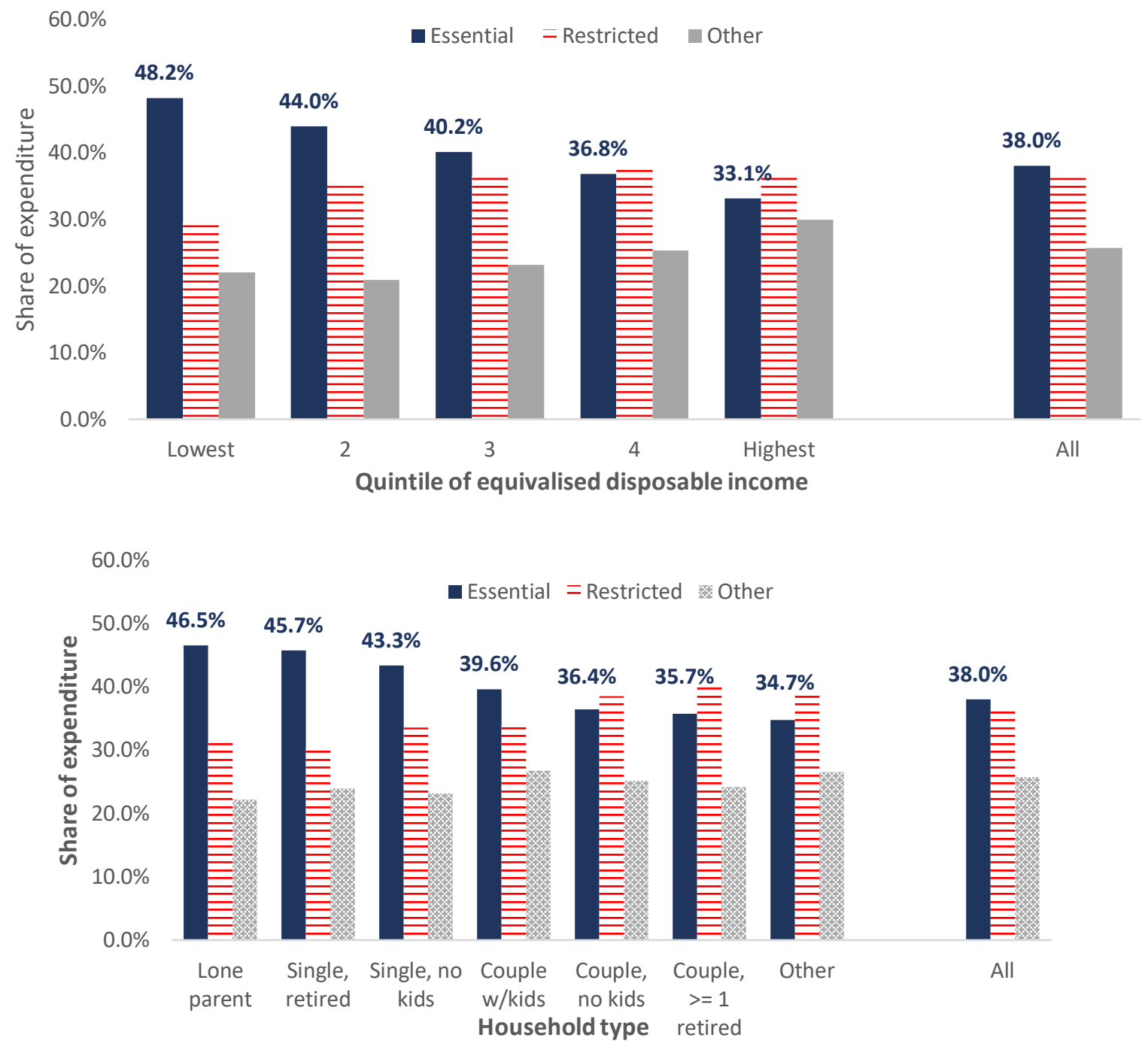

$60.0 \%$

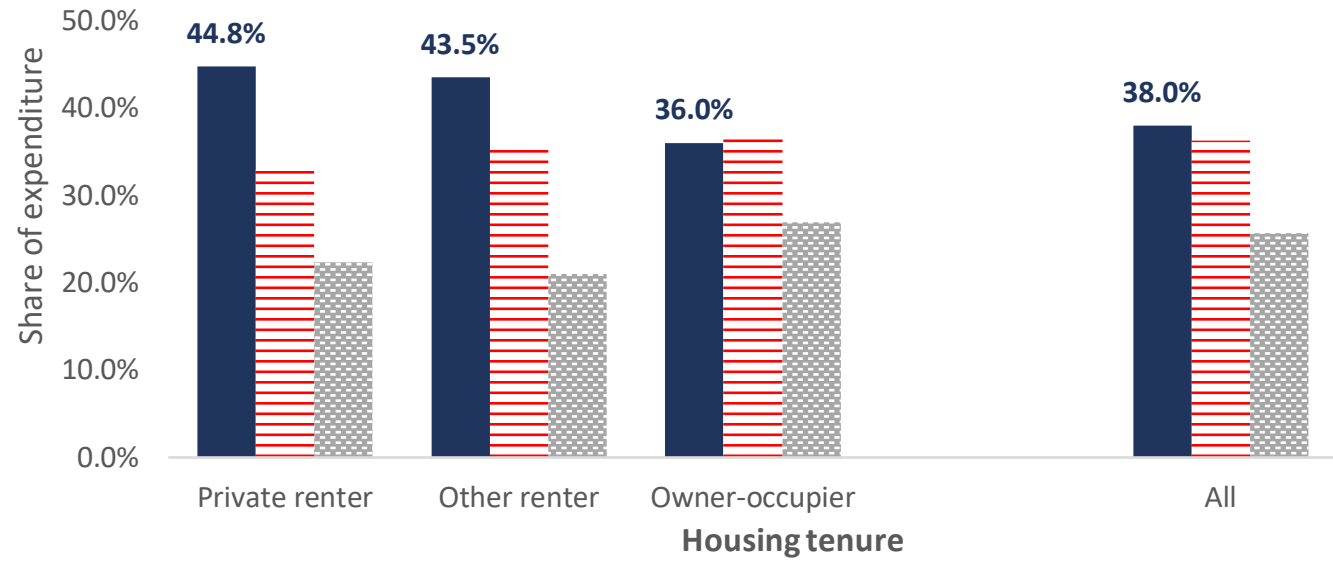

Source: $\quad$ Authors' calculations using 2015-2016 HBS; same classification as Figure 1. 



\section{SECTION 3}

\section{Estimating the change in consumption due to the pandemic}

\subsection{Context and evidence to date}

Developments in consumption during the COVID-19 pandemic are going to be affected by a combination of three intertwined factors: 1) economic adjustments to household incomes through labour market developments as well as any policy measures to support incomes; 2) regulatory restrictions on consumer behaviour which limit the basket of goods and services available for consumption as well as the effect of social distancing or other ongoing measures; and 3) discretionary changes to consumption that arise out of altered behaviours, mainly through viral infection avoidance strategies. ${ }^{3}$ Understanding the extent to which these factors impact consumption is critical to understanding the macroeconomic developments of the COVID-19 economy.

While we are still in the early phases of the crisis, a number of studies globally have already begun to map out the impact of COVID-19 on household spending. Chen et al. (2020) used data for all daily offline spending transactions in 214 Chinese cities between 1 January and 14 April 2020 to study the impact of COVID-19 on consumption following the Wuhan lockdown on 23 January. They found that aggregate consumption decreased by 32 per cent in the 12-week post-outbreak period, with a much larger decrease (-70 per cent) observed in Wuhan itself. Consumption on dinning and entertainment fell the most (-64 per cent), followed by travel-related consumption (-59 per cent) and consumption of durable goods (-35 per cent). The spending category least affected was groceries and household items (-15 per cent). Consumption on goods had fully rebounded compared to the previous year by the end of March, while consumption of services remained down by 10 per cent. Expenditure on durable goods actually increased by up to 20 per cent for a two-week period at the end of March. However, a new decrease in consumption was observable in the first two weeks of April amidst concern over a second wave of cases. Consumption of both goods and services was down by around 20 per cent in this two-week period.

Baker et al. (2020) used transaction-level household financial data to analyse the impact of the COVID-19 outbreak on the spending behaviour of a sample of the American population. Their results for states with shelter-in-place orders seem most relevant for Ireland. The authors found that, in the states with shelter-inplace orders on or prior to 27 March, overall consumption was down 25 per cent for the week of 18-27 March. Two categories of spending were isolated - spending

3 Previous research such as that by Keogh-Brown et al. (2010) shows that this channel can have sizable impacts on spending patterns during periods of disease epidemics. As more data for Ireland becomes available, research could investigate this channel in more detail. 
on restaurants was down 32 per cent while spending on groceries was up 23 per cent.

Cook et al. (2020) analysed bank spending data in England and Wales. Their data are composed of total sales linked to geo-tagged consumer-facing merchant IDs for active debit card customer for the first two weeks of lockdown. Findings indicate that sales at non-grocery suppliers fell by around 45 per cent, while spending at grocery suppliers rose by 16 per cent.

Anderson et al. (2020) indicate that a majority of the consumption changes in Denmark and Sweden during the pandemic are driven by changes in behaviours rather than restrictions or social distancing regulations. This is important in terms of understanding how spending may develop under ongoing restrictions but without a vaccine.

Data released for Ireland relating to consumer spending point to a dramatic decline in activity. Two specific sources of note are the CSO retail sales information and the Central Bank of Ireland credit card and debit card statistics, with the latter outlined in some detail in Hopkins and Sherman (2020).

Table 1 below presents the seasonally adjusted CSO retail sales data for the period January-March 2020. Column (1) presents the index average for January and February, column (2) contains the March 2020 data, while column 3 presents the percentage change between these two series. It is very clear that there was a dramatic decline in many retail sales items in Ireland in March: overall the index declined by 13 per cent relative to January and February. However, this masks considerable variation across different spending categories. For example, for bars, which were closed under government lockdown regulations from 15 March, sales fell by 50 per cent. Major declines were also seen in the motor industry as well as in footwear, clothing and textiles. Groceries and other food and drink items were up considerably, which is consistent with the evidence from other countries (Baker et al., 2020; Cook et al., 2020). 
TABLE 1 RETAIL SALES IN IRELAND (SEASONALLY ADJUSTED), JANUARY-MARCH 2020

\begin{tabular}{|l|c|c|c|}
\hline & Ave. Jan-Feb & Mar 2020 data & \% change \\
\hline Motor trades & 117.7 & 80.4 & $-32 \%$ \\
\hline $\begin{array}{l}\text { Non-specialised stores with food, } \\
\text { beverages or tobacco predominating }\end{array}$ & 121.95 & 138.1 & $13 \%$ \\
\hline Department stores & 105.75 & 79 & $-25 \%$ \\
\hline $\begin{array}{l}\text { Food, beverages and tobacco in specialised } \\
\text { stores }\end{array}$ & 108.3 & 125.9 & $16 \%$ \\
\hline Automotive fuel & 102.3 & 93.7 & $-8 \%$ \\
\hline Pharmaceutical, medical and cosmetic & 123.2 & 134.8 & $9 \%$ \\
\hline articles & 116.05 & 58.5 & $-50 \%$ \\
\hline Textiles, clothing and footwear & 166.6 & 139 & $-17 \%$ \\
\hline Furniture and lighting & 132.5 & 148.8 & $12 \%$ \\
\hline Hardware, paints and glass & 186 & 198 & $6 \%$ \\
\hline Electrical goods & 100.9 & 72.1 & $-29 \%$ \\
\hline Books, newspapers and stationery & 109.8 & 110 & $0 \%$ \\
\hline Other retail sales & 98.95 & 46.5 & $-53 \%$ \\
\hline Bars & 119.4 & 103.5 & $-13 \%$ \\
\hline All retail businesses & & & \\
\hline SO & & & \\
\hline
\end{tabular}

Source: $\quad$ CSO (2020b).

In addition to data on retail sales, the Central Bank provides detailed information on credit and debit card transactions by spending category; these data are available for March 2020. The changes relative to the average for January and February are presented in Table 2 below. Again, major declines are notable in spending categories relating to transport, entertainment, hospitality and clothing. Increases are evident in groceries, hardware and electrical goods. One limitation relating to using credit and debit card data in measuring aggregate effects is the possible substitution between card and cash transactions that may have occurred in response to COVID-19. Some households may have switched payment method rather than overall level of spending. Indeed, many consumers were actively encouraged to switch to card payments from mid-March. This is evidenced by the government announcement, made on 8 March, to increase the level of allowable contactless payments. ${ }^{4}$ If consumers increased card payments for items in substitution for cash, the credit and debit card data may over-estimate increases in spending or under-estimate declines in spending, leading to an under-estimate of the overall shock. Indeed the discrepancy between the retail sales data figure for food expenditure (up 13 per cent) and the credit/debit card data for groceries (up 43 per cent) may highlight this effect. 
TABLE 2 DEVELOPMENTS IN PERSONAL CREDIT AND DEBIT CARD EXPENDITURE

\begin{tabular}{|l|c|c|c|}
\hline \multicolumn{1}{|c|}{ Item } & $\begin{array}{c}\text { Ave Jan-Feb } \\
(€ \mathbf{0 0 0})\end{array}$ & $\begin{array}{c}\text { Mar } \\
(€ \mathbf{0 0 0})\end{array}$ & \% change \\
\hline Groceries/perishables & 862,188 & $1,230,444$ & $43 \%$ \\
\hline Clothing & 189,298 & 159,236 & $-16 \%$ \\
\hline Electrical goods & 96,786 & 100,891 & $4 \%$ \\
\hline Hardware & 267,870 & 297,212 & $11 \%$ \\
\hline Transport & 371,766 & 160,513 & $-57 \%$ \\
\hline Accommodation & 171,417 & 73,612 & $-57 \%$ \\
\hline Education & 85,443 & 30,072 & $-65 \%$ \\
\hline Health & 115,710 & 96,999 & $-16 \%$ \\
\hline Utilities & 264,495 & 218,539 & $-17 \%$ \\
\hline Professional services & 238,017 & 220,092 & $-8 \%$ \\
\hline Restaurants/Dining & 276,948 & 188,874 & $-32 \%$ \\
\hline Entertainment & 140,167 & 121,916 & $-13 \%$ \\
\hline Other & 752,484 & 853,576 & $13 \%$ \\
\hline
\end{tabular}

Source: Central Bank of Ireland Data. Data are taken from CBI release Table A.13, and relate to the value of new spending on personal credit and debit cards.

It is clear that the COVID-19 pandemic has had a major effect on household spending. The figures presented for March above are stark and point to a major reorientation of expenditure amidst an overall fall. Indeed, given that the broad lockdown of economic and social life was only introduced on 28 March, these data do not take into consideration many of the physical restrictions on spending that are currently operating (these data likely reflect behavioural changes in expenditure). The spending data for April are likely to show further declines in many categories. High level aggregate credit card data for April already show a decline of 30 per cent relative to the March data. ${ }^{5}$

\subsection{Scenario design, methodology and data}

We develop alternative pathways for household spending in 2020 in the context of the COVID-19 pandemic. We parameterise three specific scenarios built around the current government Roadmap out to August 2020 and three potential epidemiological developments for the rest of 2020. These scenarios draw on the existing international research and also use inputs from the Irish data sources where possible. The scenarios are:

a) 'new normal' - Baseline;

b) 'second wave' - Severe case;

c) 'vaccine' - Return to normal.

For the baseline scenario, we assume that the government Roadmap is successful at supressing the disease in the community to a degree that allows the plan to be 
fully implemented out to August 2020. For the rest of 2020, we assume that ongoing social and physical distancing is required, and some limitations will be placed on economic and social life. These are required under the assumption that COVID-19 will not be eradicated in the community and in the absence of a vaccine or other medical developments to maintain low infection rates. We allow some pick up in economic activity in the final quarter, as households adjust to the new normal, but there is some permanent loss of output.

For the severe scenario, we again assume that the Roadmap successfully reopens the economy and social activity through to end September but that COVID-19 remains in the community and infection numbers increase during a second wave. We assume this will lead to a reintroduction of strict lockdown measures for the final three months of the year. ${ }^{6}$

The final scenario that we deploy assumes rapid vaccine advances which lead to a more rapid return to normal activity than is currently envisaged. The consequence is the renormalisation of economic relationships at a more rapid rate, leading to economic activity returning to normal in the final quarter of the year. ${ }^{7}$

Critical to the above scenarios is the current Roadmap for reopening economic and social life. This Roadmap contains a five-phased reopening strategy, from the strict lockdown which ran from 28 March to 17 May, right through to August where a majority of activities will be reopened. Across these phases, consumers will be able to reengage with a wider set of goods and services as part of their consumption bundles. These phases are linked to each scenario and dated as shown in Table 3.

TABLE 3 PHASES AND SCENARIOS

\begin{tabular}{|c|c|c|c|}
\hline & $\begin{array}{l}\text { New normal } \\
\text { (Baseline) }\end{array}$ & Second wave (Severe) & Vaccine \\
\hline 28 March-17 May & Lockdown & Lockdown & Lockdown \\
\hline 18 May-7 June & Phase 1 & Phase 1 & Phase 1 \\
\hline 8-28 June & Phase 2 & Phase 2 & Phase 2 \\
\hline 29 June-19 July & Phase 3 & Phase 3 & Phase 3 \\
\hline 20 July-9 August & Phase 4 & Phase 4 & Phase 4 \\
\hline $\begin{array}{l}10 \text { August-end Quarter } \\
3\end{array}$ & Phase 5 & Phase 5 & Phase 5 \\
\hline Quarter 4 & $\begin{array}{l}\text { Ongoing physical and } \\
\text { social distancing to end } \\
2020\end{array}$ & $\begin{array}{l}\text { Second wave, strict } \\
\text { lockdown for } 12 \text { weeks }\end{array}$ & $\begin{array}{c}\text { Normal economic } \\
\text { activity }\end{array}$ \\
\hline
\end{tabular}

6 It must be noted that this severe scenario would underestimate the impact on consumption if epidemiological developments do not allow the Roadmap to progress as planned or a resumption to lockdown occurs earlier than Q4. 7 The scenarios were set to closely align to the upcoming ESRI Quarterly Economic Commentary (McQuinn et al., 2020). However, there may be some differences in timelines between this research and the QEC. 



\section{SECTION 4}

\section{Empirical analysis}

\subsection{Pandemic changes to household consumption}

Details of the calibration of the three scenarios can be found in Appendices $A$ and B. The value weighted parameters (initial spending level and expenditure parameter) for a typical week in each of the phases is presented in Table 4 below. We hold fuel and light and housing costs constant in real terms, other than a limited number of items relating to maintenance and renovations items in housing.

TABLE 4 FIGURES FOR EXPENDITURE IN A TYPICAL PHASE WEEK - DEVIATIONS FROM CASE CASE (\%)

\begin{tabular}{|l|c|c|c|c|c|c|c|c|}
\hline & March & Shutdown & Phase 1 & Phase 2 & Phase 3 & Phase 4 & Phase 5 & $\begin{array}{c}\text { New } \\
\text { normal }\end{array}$ \\
\hline Food & 4 & -9 & -9 & -9 & 0 & 0 & 0 & 4 \\
\hline $\begin{array}{l}\text { Drink and } \\
\text { tobacco }\end{array}$ & -14 & -31 & -31 & -31 & -31 & -31 & -14 & -14 \\
\hline $\begin{array}{l}\text { Clothing and } \\
\text { footwear }\end{array}$ & -50 & -64 & -64 & -50 & -50 & -50 & 0 & 0 \\
\hline Light and fuel & 0 & 0 & 0 & 0 & 0 & 0 & 0 & 0 \\
\hline Housing & 0 & -12 & 0 & 0 & 0 & 0 & 0 & 0 \\
\hline Non-durables & 12 & 12 & 4 & 4 & 4 & 3 & 3 & 3 \\
\hline Durables & -4 & -98 & -4 & -8 & -8 & -8 & -8 & 0 \\
\hline Transport & -21 & -73 & -62 & -56 & -51 & -49 & -46 & -16 \\
\hline Miscellaneous & -16 & -33 & -29 & -26 & -25 & -21 & -19 & -8 \\
\hline Total & -10 & -32 & -24 & -22 & -19 & -18 & -14 & -5 \\
\hline
\end{tabular}

Spending in weeks associated with the strict lockdown is down 32 per cent. This is contrasted with scenarios for the new normal (where social distancing applies), whereby expenditure is down only five per cent. Combinations of these weekly figures provide the overall scenario impacts.

\subsection{Main empirical results}

Applying these mappings and parameters to each phase, and then aggregating up to an annual spending figure, provides the following estimates of household spending under each scenario (Table 5). 
TABLE 5 ANNUAL CHANGES TO CONSUMPTION BY SCENARIO (\%)

\begin{tabular}{l|c|c|c|}
\hline & New normal & Second wave & Vaccine \\
\hline Food & -1 & -4 & -2 \\
\hline Drink and tobacco & -18 & -22 & -14 \\
\hline Clothing and footwear & -25 & -41 & -25 \\
\hline Light and fuel & 0 & 0 & 0 \\
\hline Housing & -2 & -4 & -2 \\
\hline Non-durables & 5 & 7 & 4 \\
\hline Durables & -16 & -38 & -16 \\
\hline Transport & -34 & -48 & -30 \\
\hline Miscellaneous & -16 & -22 & -14 \\
\hline Total & -13 & -20 & -12 \\
\hline Note: Authors' calculations using data from the HBS (2015-2016). & \\
\hline
\end{tabular}

Under the baseline 'new normal' scenario, whereby consumption returns under ongoing physical and social distancing, household expenditure is likely to be 13 per cent lower in 2020 than in 2019. The biggest adjustments occur in the clothing and footwear, as well as transport categories, which are down 25 and 34 per cent respectively. Expenditure on food is down marginally as the increased spend on eating at home is outweighed by a reduction in expenditure outside the home. Expenditure on non-durables is up slightly, reflecting the March bounce in the CSO data and our assumption of higher-than-normal expenditure on cleaning products and other items in light of the requirement for ongoing hygiene measures.

In the 'severe' scenario, where a strict lockdown has to be reintroduced for a 12week period from October, the total fall in consumption in 2020 relative to 2019 is 20 percent. In this scenario, clothing and footwear, durables and transport expenditure are all down - close to, or above, 40 per cent relative to the nopandemic scenario.

The final scenario we consider is the case whereby a vaccine becomes available such that normal economic activity can resume for the whole of Quarter 4 . Applying these assumptions, household spending will be down nearly 12 per cent in the year. This figure is close to the 'new normal' scenario, which highlights the extent to which the spending shock has already occurred. A degree of economic damage will materialise even if normality resumes towards the end of the year.

\subsection{Implications for VAT expenditure}

To calculate the impact of COVID-19 related consumption changes on indirect tax revenue, we use the indirect tax microsimulation model, ITSim, jointly developed by researchers at the ESRI and the Department of Finance. ITSim estimates the indirect taxes (VAT and excise duties, including carbon taxes) paid by Irish households on the basis of their reported expenditure, collected by the CSO's 
nationally representative HBS in 2015-2016, and adjusted to be representative of $2020 .{ }^{8}$ We apply the current (May 2020) rates of VAT and excise duties to these uprated expenditures to estimate the amount of indirect taxes paid by each household, and - modifying their consumption in line with the scenarios outlined in the previous section - how much indirect tax they might pay in 2020.

Figure 3 shows the estimated weekly indirect tax paid by households on average in each phase of the pandemic that we model. The estimate that average weekly indirect tax paid in the pre-pandemic 'normal' phase is €111 per household. We estimate this fell to $€ 54$ per household per week in the 'shutdown' phase, with a gradual recovery through each phase of the reopening until it reaches a 'new normal' of $€ 105$ per week following Phase 5 .

Next, we look at the simulated impact on indirect tax revenues in each of our scenarios, which differ in the length of time that is spent in each phase.

FIGURE 3 AVERAGE WEEKLY INDIRECT TAX PAID PER HOUSEHOLD IN EACH PHASE OF THE PANDEMIC ( $€$ PER WEEK)

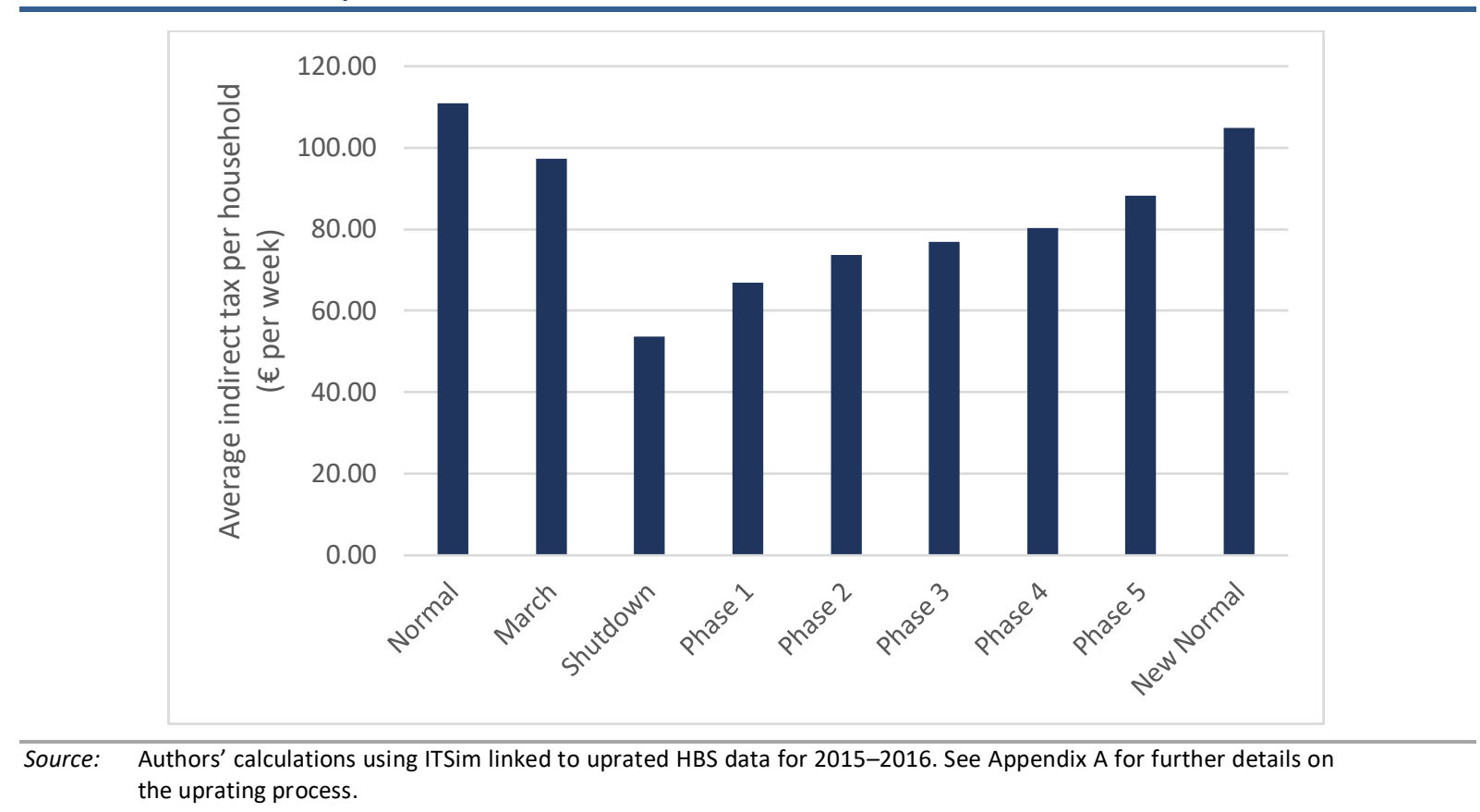

8 We uprate expenditure to 2019 terms using official statistics from the CSO and assume no growth between 2019 and 2020. See Appendix A for further detail on the uprating process. 
FIGURE 4 SIMULATED CHANGE IN INDIRECT TAX REVENUE UNDER DIFFERENT PANDEMIC SCENARIOS $(100=2019)$

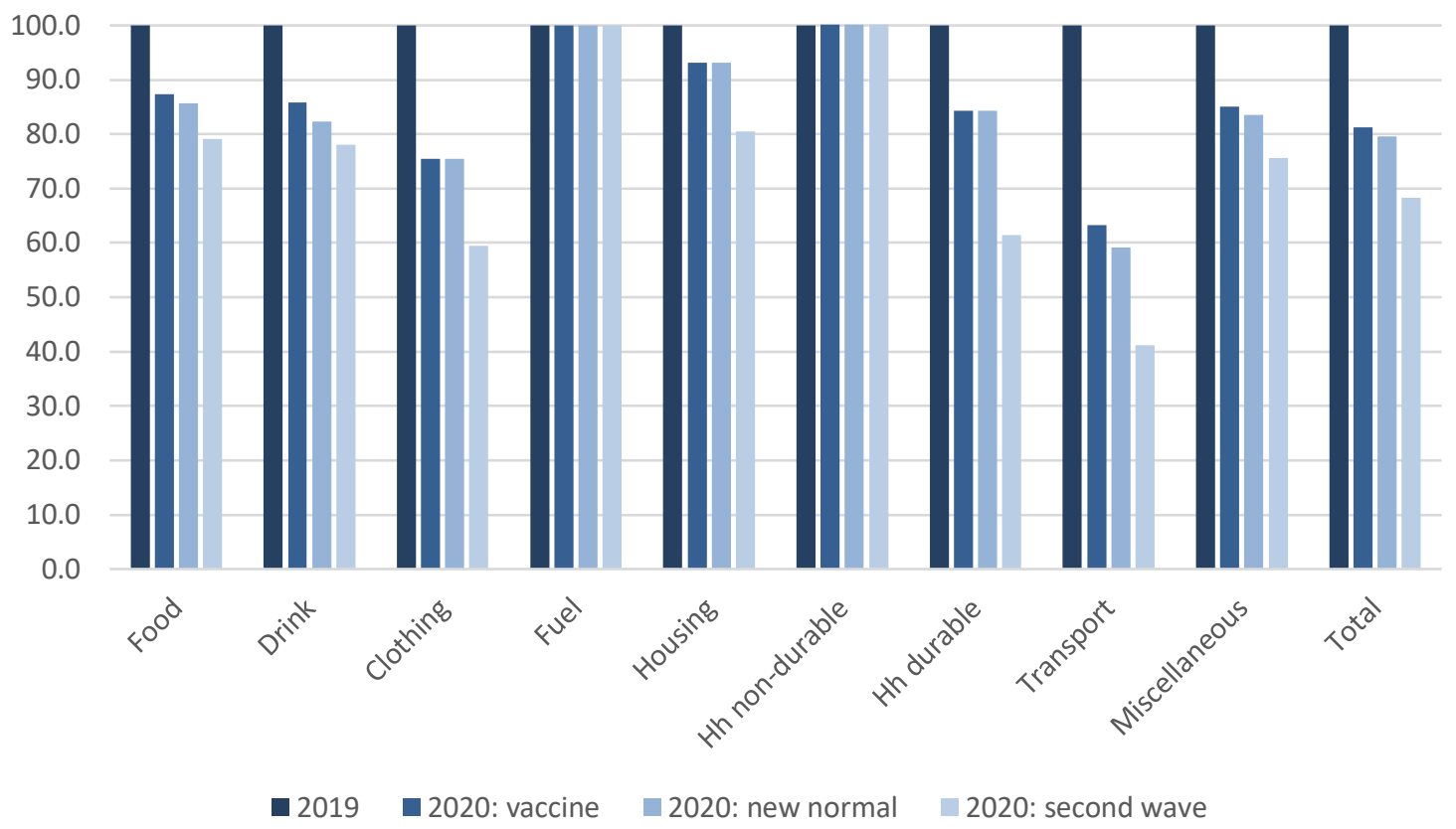

Source: Authors' calculations using ITSim linked to uprated HBS data for 2015-2016. See Appendix A for more details on the uprating process. Scenarios as described in Section 3, with indirect tax indexed to estimated no-pandemic level at 100.

Figure 4 shows how the annual change in consumption in each scenario translates into a change in indirect tax revenue. We simulate that, overall, indirect taxes decline by 20.5 per cent in the 'new normal' scenario, 18.7 per cent in our 'vaccine' scenario and 31.7 per cent in our 'second wave' scenario. According to the Department of Finance (2020), a total of $€ 21.1$ billion was collected in indirect tax revenues in 2019, suggesting a reduction of $€ 4.3$ billion for the baseline scenario, $€ 3.9$ billion for the benign scenario and $€ 6.7$ billion for the severe scenario. The largest contributor to this reduction is the decline in transport spending, with much of this subject not only to VAT at 23 per cent but also fuel duty and the carbon tax. We also estimate that revenue from expenditure on food and drink falls by between 12 and 22 per cent. This is because meals out and drink purchases in pubs or restaurants constitute a significant share of such spending, are subject to a higher rate of tax than groceries, and are highly affected by the shutdown. 


\section{SECTION 5}

\section{Conclusion}

This paper has examined the potential effects of the COVID-19 pandemic on consumption and indirect tax in Ireland. It shows that essential items make up a larger share of the expenditure of lower income, single and renting households than others. Beirne et al. (2020) found that the Pandemic Unemployment Payment (PUP) and Temporary Wage Subsidy Scheme (TWSS) played an especially important role for such households in mitigating the income shock arising from Covid-19 related job losses. This suggests that particular attention should be given to these groups in the design of any revised schemes as they will find it more difficult that others to weather a sustained income shock.

It then considered three scenarios for household consumption built around the current government Roadmap and potential epidemiological developments for the rest of 2020. In all scenarios, we assume that the government Roadmap is followed out to the end of the third quarter, while regarding Quarter 4 we vary economic activity along three differing economic paths: a) a new normal with continued physical distancing; b) a second wave strict lockdown; and c) a vaccine that allows a return to normal economic activity. Under these scenarios, we estimate that consumption would be 13, 20 and 12 per cent lower in 2020 than in 2019 respectively. These scenarios highlight the scale of the shock to household spending in 2020 that can be expected given the COVID-19 pandemic. Indeed, the scale of the economic damage caused by COVID-19 is clear from the medical advances scenario; even with a medical intervention and a return to normal economic activity in Quarter 4, the drop in spending is likely to be in the region of 12 per cent. $^{9}$

In all our scenarios, we assume that the government Roadmap for reopening Ireland follows the current timeline out to the end of Quarter 3. This assumption abstracts from any anticipatory feedback loops between epidemiological developments and household spending whereby households see reductions (increases) in viral transmission and then change their behaviour ahead of Quarter 4 of 2020. These effects may lead to a larger reduction consumption from a second wave or a bigger spending boost following a return towards more normal spending ahead of a strict time cut off in Quarter 4 of 2020. However, if these changes are purely transitory in nature the net effect across the year is difficult to estimate. Our method works on a strict timeline basis without cross period anticipation. 
Finally the paper examines the implications of these scenarios for indirect tax revenues, finding that these could decline by between one-fifth and one-third, with reductions driven by declines in tax from transport, drink and meals out.

A number of avenues for future research could be considered. First, no adjustments have been made to the level of expenditure on housing and fuel and light in real terms. One useful step forward would be to loosen this assumption and work through how changes to relative rental prices or mortgage payments in particular might affect households. Second, further scenarios could be tested in future that adjust the timelines for the government Roadmap, if clear epidemiological data become available pointing to whether these timelines may be exceeded or extended. Third, we have not considered the distributional impacts of the consumption shocks or linked these to income changes. This would be a very worthwhile step for future analysis. 


\section{REFERENCES}

Andersen, A., E. Hansen, N. Johannesen and A, Sheridan (2020). 'Pandemic, shutdown and consumer spending: Lessons from Scandinavian policy responses to COVID19', arXiv:2005.04630.

Beirne, K., K. Doorley, M. Regan, B. Roantree and D. Tuda (2020). 'The potential costs and distributional impact of COVID-19 related unemployment in Ireland', Budget Perspectives, Paper 1, ESRI, Dublin.

Chen, H., W. Qian and Q. Wen (2020). 'The impact of the COVID-19 pandemic on consumption: Learning from high frequency transaction data', SSRN (6 April), https://ssrn.com/abstract=3568574

Central Statistics Office, (2020a). Household finance and consumption survey 2018, https://www.cso.ie/en/releasesandpublications/ep/phfcs/householdfinanceandconsumptionsurvey2018/.

Central Statistics Office (2020b). 'Retail sales index, provision March data', https://www.cso.ie/en/releasesandpublications/er/rsi/retailsalesindexmarch202 $0 /$.

Cook, C., E. Hollowood and C. Newell (2020). 'Corona shock: Week II', Tortoise, https://members.tortoisemedia.com/2020/04/28/corona-shock-week2/content.html.

Department of Finance (2020). 'Annual Taxation Report 2020', https://www.gov.ie/en/publication/2857fa-annual-taxation-report-2020/

Baker, S., R. Farrokhnia, S. Meyer, M. Pagel and C. Yannelis (2020). 'How does household spending respond to an epidemic? Consumption during the 2020 COVID-19 pandemic', NBER Working Papers 26949, National Bureau of Economic Research, Inc.

Hopkins, A. and M. Sherman (2020). 'How has the COVID-19 pandemic affected daily spending patterns?', Central Bank of Ireland (April), https://www.centralbank.ie/statistics/statistical-publications.

Irish Government (2020). 'Roadmap for reopening society and business', https://www.gov.ie/en/news/58bc8b-taoiseach-announces-roadmap-forreopening-society-and-business-and-u/.

Keogh-Brown, M.R., S. Wren-Lewis, W.J. Edmunds, P. Beutels and R.D. Smith (2010). 'The possible macroeconomic impact on the UK of an influenza pandemic', Health Economics, Vol. 19, Issue 11, pp. 1345-1360.

McQuinn, K., C. O’Toole, M. Allen-Coghlan and C. Coffey (2020). Quarterly economic commentary, summer 2020, Economic and Social Research Institute. 



\section{APPENDIX A}

\section{Scenario phasing and calibration}

Before we carry out our analysis of consumption under the different scenarios, we uprate the data in the Household Budget Survey (HBS). The HBS documents the average weekly spending of households. This is broken down across a huge variety of categories and gives an insight into the spending patterns of households. The most recent HBS available to us was carried out between February 2015 and February 2016. We uprate consumption expenditure across all categories to 2019 levels using a scalar based on the growth of the 'personal expenditure on consumer goods and services' component of the expenditure on gross national product at current market prices. ${ }^{10}$ This uprating results in a change to the level of consumption expenditure but the size of household expenditure in one category relative to another is not affected by this transformation. We assume that household expenditure in a 'normal' week in 2020 is equal to weekly household expenditure in 2019. An implicit assumption in this is that there is no growth in the consumption expenditure of households between 2019 and 2020.

To calibrate the three consumption scenarios, we first assume that household expenditure differs across each of the phases above, as well as from 10 August to 31 December 2020. Second, we use a combination of existing data, the emerging empirical literature and judgement to map calibrated expenditure parameters to all categories in the HBS. We allow these parameters to vary these across the phases outlined above and to differ for Quarter 42020.

More specifically, we deploy a bottom-up simulation tool that adjusts household spending from micro data in each time period of the Roadmap phases, as well as from 20 August to 31 December. For example, we assume a very low level of expenditure on many non-essential items during the lockdown phase that gradually recovers through to end 2020. We set expenditure parameters to accord to each phase individually, which we apply to the relevant share of the year.

In terms of the first methodological step, we differ across scenarios mainly in the final quarter of the year. The dates at which each varying parameter set are applied is presented in Table A1 below.

10 This is published on the CSO website, available at: 
TABLE A1RELEVANT PERIODS, 2020

\begin{tabular}{l|l|l|l|}
\hline \multicolumn{1}{c|}{ Date } & \multicolumn{1}{c|}{ New normal } & \multicolumn{1}{c}{ Vaccine } & \multicolumn{1}{c}{ Second wave } \\
\hline 1 Jan-29 Feb & Normal & Normal & Normal \\
\hline 1-31 Mar & March & March & March \\
\hline 1 Apr-17 May & Lockdown & Lockdown & Lockdown \\
\hline 18 May-7 Jun & Phase1 & Phase1 & Phase1 \\
\hline 8-28 Jun & Phase2 & Phase2 & Phase2 \\
\hline 29 Jun-19 Jul & Phase3 & Phase3 & Phase3 \\
\hline 20 Jul-9 Aug & Phase4 & Phase4 & Phase4 \\
\hline 10 Aug-30 Sept & Phase5 & Phase5 & Phase5 \\
\hline 1 Oct-31 Dec & New Normal & Normal & Lockdown + Phase \\
\hline
\end{tabular}

Figure 1 below presents the share of days in the calendar year for each of the scenarios. For the baseline 'new normal' scenario, 16 per cent of the year is spent under normal economic conditions and 13 per cent in full lockdown. We then move through the reopening until the final quarter is spent in a new normal activity. The major differences between the alternative scenarios can be seen in the share of time under normal conditions in the medical intervention case (over 42 per cent of the year) and the 36 per cent of time spent under severe lockdown in the second wave scenario.

\section{FIGURE A1 NUMBER OF DAYS SPENT IN EACH PHASE BY SCENARIO}

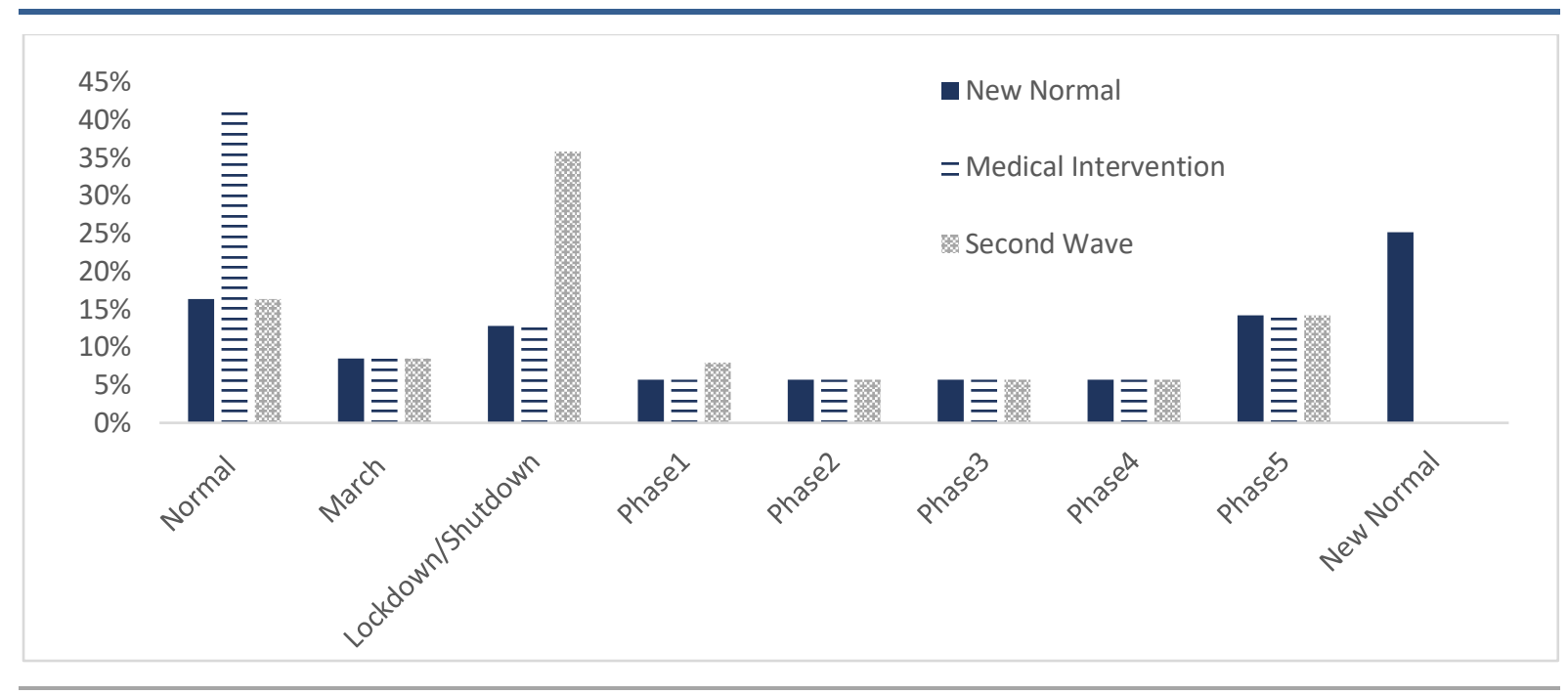




\section{APPENDIX B}

\section{Microdata and parameterisation}

The second step in our methodology is to parameterise the expenditure of households in each of the above phases. Our approach to this analysis is to use a combination of the CSO retail sales data, the CBI credit card data, the existing research and judgement to set a plausible expenditure level relative to the nopandemic case for each spending item across the time periods outlined above. We then take these parameters and adjust each households' level of expenditure by the shocked parameter. These adjusted levels are then reaggregated to get a new scenario level of consumption. We can then compare the counterfactual total level of consumption in each scenario relative to the unadjusted level, i.e. the original consumption bundle. ${ }^{11}$ The detailed mappings are outlined in Appendix A. ${ }^{12}$ As our focus is on consumption and indirect taxation receipts, we have assumed that housing expenditure, with the exception of some minor categories, ${ }^{13}$ is unchanged across the scenarios. We also hold constant spending on fuel, heat and light.

The HBS contains detail on a range of expenditure items that can be summarised in the following high-level categories:

- food (at home and away from home);

- drink and tobacco (both at home and outside the home);

- clothing and footwear;

- light and fuel;

- housing (including rent, mortgage payments, utilities as well as maintenance expenditure, upkeep and improvements);

- non-durables (disinfectants, detergents, toiletries, cosmetics, etc.);

- durables (furniture, white goods, kitchen utensils, other household hardware and electrical goods, garden items, etc.);

- transport; and

- miscellaneous.

The miscellaneous category relates to medical expenses, communications, admission and subscription charges, betting, childcare, education and training,

\footnotetext{
11 One assumption made in this analysis is particularly important. We assume that the initial shares of expenditure remain those from the $2015-2016$ HBS. We do not uprate prices and quantities to update the expenditure shares across households.

12 Further detail is available from the authors on request.

13 We adjust expenditure on house fit out, upkeep and maintenance, and other related hardware items. For more information, please contact the authors.
} 
games, sports, holidays, insurance and professional service fees, personal goods, as well as other items.

As an illustration of this mapping process across the phases, consider the following worked example. In the HBS, expenditure on food is broken down into two items: 1) total food consumed at home and 2) meals away from home. Total food consumed at home is parameterised to the CSO data for March on retail sale of good. Meals outside the home for March are mapped to the CBI data on restaurants and dining. From the March position, our calibration of these items across the phases is outlined in Table B2.

\section{TABLE B1EXAMPLE OF MAPPING}

\begin{tabular}{|c|c|c|c|c|c|c|c|c|c|c|}
\hline Item & Mapped To & $\begin{array}{c}\text { Norm } \\
\text { al }\end{array}$ & $\begin{array}{c}\text { Marc } \\
\text { h }\end{array}$ & $\begin{array}{l}\text { Lockd } \\
\text { own }\end{array}$ & $\begin{array}{c}\text { Phase } \\
1\end{array}$ & $\begin{array}{c}\text { Phase } \\
2\end{array}$ & $\begin{array}{c}\text { Phase } \\
3\end{array}$ & $\begin{array}{c}\text { Phase } \\
4\end{array}$ & $\begin{array}{c}\text { Phase } \\
5\end{array}$ & $\begin{array}{l}\text { New } \\
\text { norm } \\
\text { al }\end{array}$ \\
\hline $\begin{array}{l}01 \text { Total } \\
\text { food }\end{array}$ & & & & & & & & & & \\
\hline $\begin{array}{l}01.01 \text { Total } \\
\text { food } \\
\text { consumed at } \\
\text { home }\end{array}$ & $\begin{array}{l}\text { Retail sale } \\
\text { of food } \\
\text { (CSO) }\end{array}$ & 1 & 1.13 & 1.13 & 1.13 & 1.13 & 1.13 & 1.13 & 1.13 & 1.13 \\
\hline $\begin{array}{l}01.02 \text { Meals } \\
\text { away from } \\
\text { home (incl. } \\
\text { takeout } \\
\text { tea/coffee) }\end{array}$ & $\begin{array}{l}\text { Restaurant } \\
\text { s/ dining } \\
\text { (Central } \\
\text { Bank credit } \\
\text { card data) }\end{array}$ & 1 & 0.68 & 0.10 & 0.10 & 0.1 & 0.50 & 0.50 & 0.50 & 0.68 \\
\hline
\end{tabular}

The CSO data on retail sale of good show an increase of 13 per cent for March. We map spending on goods consumed at home to these data for March and assume this holds out to the end of 2020 , as households continue to consume food at home.

For meals outside the home, we use the data from the Central Bank credit card database, which indicate a 32 per cent fall from the January/February average (as noted in Table B1 above). We set spending on this item to 68 per cent of its normal level for March. During the strict lockdown, we set spending on this category to 10 per cent. ${ }^{14}$ We hold this level of expenditure through to Phase 3 (here marked in green), as this is when restaurants are due to reopen, according to the current government Roadmap, and augment expenditure to 50 per cent in this area in Phase 3. For Quarter 4, we assume that restaurants and dinning expenditure recovers to March levels, though also assuming a permanent loss of economic 
activity for the year as ongoing changes in behaviours to avoid infection as well as the ongoing presence of social distancing measures lead to below-normal levels of occupancy and activity.

Table B2 documents the data sources we used to help parameterise the consumption path of the items in the HBS. It also shows some of the events outlined in the Government's Roadmap that may affect the consumption path of the HBS items outlined below. 


\section{HBS spending item}

\section{Total food}

02 Total drink and tobacco

\section{Total clothing and footwear}

\section{Total fuel and light}

\section{Total housing}

06 Total household non-durable goods

07 Total household durable goods

\section{Data mapping for March/April}

01.01: CSO* - Retail sales of food

01.02: $\mathrm{CBI}^{*}$ - Spending during the month on

restaurants/dining. Information provided the Restaurants Association of Ireland (RAI) was also used.

02.01: CSO* - Retail sales of food.

02.02: CSO* - Bars

02.03: No change

$03.01-3.18$ : CSO* - Retail sale of textiles, clothing and footwear

\subsection{1 - 04.04: No change}

05.01 - 05.12: No change

$05.13-05.15$ : CSO*- Retail sale of hardware, paints and glass

05.16 - 05.17: No change

05.18 - 05.24: CSO* - Retail sale of hardware, paints and glass

06.01 - 06.10: CSO* - Retail sale in non-specialised stores with food, beverages or tobacco predominating

07.01 - 07.02: $\mathrm{CSO}^{*}$ - Retail sale of furniture and lighting 07.03 - 07.04: CSO* - Retail sale of textiles, clothing and footwear

07.05 - 07.14: CSO* - Retail sale of household equipment

07.15: No change

07.16-07.38: CSO* - Retail sale of household equipment 07.39: CSO* - All retail businesses, excluding motor trades, automotive fuel and bars

07.40: CSO* - Retail sale of household equipment

\section{Some of the key phase events parameterised}

Phase 3:

Restaurants and cafes can reopen with physical distancing.

Phase 5:

- Pubs/ Bars can reopen.

Phase 2:

Small retail outlets can reopen.

Phase 5:

- Shopping centres can reopen.

N/A

Phase 1:

- $\quad$ Construction can resume and hardware shops can reopen.

Phase 4:

- Hairdressers/barbers can reopen.

Phase 1:

Reopening of:

garden centres and hardware stores,

providers of office products and services;

stores involved in electrical, IT and phone sales,

repair and maintenance services home. 
07.41 - 07.44: CSO* - All retail businesses, excluding motor trades, automotive fuel and bars

07.45: CSO* - Retail sale of electrical goods

07.46: CSO* - Retail sale in non-specialised stores with

food, beverages or tobacco predominating.

08.01: CSO* - Motor trades and SIMI* - 2020 total new vehicle registrations.

08:02: CSO* - Retail sale of automotive fuel

08.03: No change

\section{Total transport}

09 Total miscellaneous goods, services, and other expenditure
08.04: CSO* - Motor trades

08.05: $\mathrm{CBI}^{*}$ - Spending during the month on transport. 08.06: Some elements of this spending category were left unchanged while some were parameterised using $\mathrm{CBI}$ * data (spending during the month on transport) and Ryanair data were also used.

09.01: $\mathrm{CBI} *$ - Spending during the month on health

09.02 -09.03: No change

09.04: $\mathrm{CBI}{ }^{*}$ - Spending during the month on

entertainment and the number of days in March that schools/gatherings were closed/restricted.

09:05: No change

09:06: CSO* - Retail sale of books, newspapers, and stationery

09:07: Some elements of this spending category were left unchanged while some were parameterised using $\mathrm{CBI}$ * data (spending during the month on education).

09.08: $\mathrm{CBI}$ * data - Spending during the month on entertainment

09:09: Ryanair data

09.10 -09:11: No change
Phase 1:

- Retailers involved in the sale, supply and repair of motor vehicles, motorcycles and bicycles and related facilities can open.

Phases 1-5:

- As more people return to work \& travel restrictions loosen spending on transport is expected to increase.

Phase 1:

- Increased delivery of non-Covid related medical care.

Phase 2:

- Small retail outlets can reopen with a small number of staff and control number of people in shop at once.

Phase 3:

The opening of all other non-essential retail outlets will be phased in on the basis of a restriction on the number of staff and customers per square metre.

Phase 4:

- Competition sport can resume with social distancing and a limited number of spectators. 
09.12: $\mathrm{CBI}$ * data - Spending during the month on professional services.

09.13: CSO* - Retail sale of hardware, paints and glass

09.14: $\mathrm{CBI}$ * data - Spending during the month on

professional services

09.15: CSO* - Other retail sales and retail sale of textiles,

clothing and footwear

09.16: No change.

09.17: Some elements of this spending category were left unchanged while others were parameterised using $\mathrm{CBI}$ * data (spending during the month on health) and the number of days in March that schools were closed.

09:18: No change

09.19: Some elements of this spending category were left unchanged while others were parameterised using $\mathrm{CBI}$ * data (spending during the month on restaurants/dining and on total services).
- Museums, galleries, and other cultural outlets can be opened with social distancing in place.

Phase 5:

- A phased return to work across all sectors.

Cinemas, theatres, gyms, dance studios and sports clubs can reopen, only where regular and effective cleaning can be carried out and social distancing can be maintained.

Festivals, events and other social and cultural mass gatherings can take place only in accordance with both indoor and outdoor number restrictions.

Phases 1-5:

- $\quad$ Spending on childcare is expected to increase across the phases as more people return to work.

CSO*: The specific CSO Retail Sales Indices used are the Volume Adjusted Retail Sales Indices (Base 2015=100) published by the CSO at https://statbank.cso.ie/px/pxeirestat/Statire/SelectVarVal/Define.asp? maintable=RSM05\&PLanguage=0.

CBI*: The Central Bank of Ireland (CBI) provide data in relation to credit and debit card transactions including a sectoral breakdown of expenditure. This is available at https://www.centralbank.ie/statistics/data-and-analysis/credit-and-banking-statistics/credit-and-debit-card-statistics.

SIMI: Society of the Irish Motor Industry. Data on new vehicle registrations in 2020 available at https://www.simi.ie/en/news/96-decline-in-april-car-registrations-motor-industryprepares-for-social-distance-selling.

Restaurant Association of Ireland: Correspondence with the RAl.

Ryanair: Ryanair publish statistics on the volume of their air traffic, available at https://investor.ryanair.com/traffic/.

Irish Government (2020), 'Roadmap for reopening society and business', available at https://www.gov.ie/en/news/58bc8b-taoiseach-announces-roadmap-for-reopening-societyand-business-and-u/ 
Whitaker Square,

Sir John Rogerson's Quay,

Dublin 2

Telephone +35318632000

Email admin@esri.ie

Web www.esri.ie

Twitter @ESRIDublin 